\title{
Expression of renal 11ß-hydroxysteroid dehydrogenase type 2 is decreased in patients with impaired renal function
}

\author{
Marcus Quinkler ${ }^{1,3}$, Daniel Zehnder ${ }^{2}$, Julia Lepenies ${ }^{2}$, Massimiliano D Petrelli ${ }^{1}$, Jasbir S Moore ${ }^{1}$, Susan V Hughes ${ }^{1}$, \\ Paul Cockwell ${ }^{2}$, Martin Hewison ${ }^{1}$ and Paul M Stewart ${ }^{1}$ \\ ${ }^{1}$ Division of Medical Sciences and ${ }^{2}$ Department of Nephrology, University of Birmingham, Queen Elizabeth Hospital, Edgbaston, Birmingham B15 2TH, \\ UK and ${ }^{3}$ Division of Clinical Endocrinology, Campus Mitte, Charité University-Medicine Berlin, Berlin, Germany
}

(Correspondence should be addressed to P M Stewart, Division of Medical Sciences, Institute of Biomedical Research, Medical School, University of Birmingham, Birmingham B15 2TT, UK; Email: p.m.stewart@bham.ac.uk)

\begin{abstract}

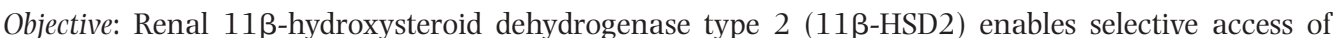
aldosterone to the mineralocorticoid receptor (MR). Impaired 11 $\beta$-HSD2 activity has been suggested in patients with hypertension as well as in patients with renal disease, where it may contribute to sodium retention, oedema and hypertension. To date, these studies have relied upon urinary cortisol (F) metabolite levels as surrogate markers of renal 11 $\beta$-HSD2 activity.

Methods: We have directly analysed renal 11ß-HSD2 mRNA expression in 95 patients undergoing kidney biopsy using TaqMan real-time PCR. Serum and 24-h urine samples were used to document underlying renal function and endocrine parameters. Urinary F and cortisone (E) metabolites were analysed using gas chromatography/mass spectrometry.

Results: Expression of $11 \beta-\mathrm{HSD} 2$ did not correlate with blood pressure or urinary Na/K ratio, but a significant positive correlation with creatinine clearance was observed $(r=0.284 ; P<0.01)$. Immunofluorescence and confocal laser microscopy confirmed decreased 11 $\beta$-HSD2 expression in patients with impaired renal function. For the first time, we showed that $11 \beta-H S D 2$ mRNA expression correlated negatively with the urinary free (UF) F/E (UFF/UFE) ratio $(r=0.276 ; P<0.05)$ as well as with the urinary tetrahydrocortisol $+5 \alpha$-tetrahydrocortisol/tetrahydrocortisone ((THF $+\alpha \mathrm{THF}) / \mathrm{THE})$ ratio $(r=0.256 ; P<0.05)$. No difference in $11 \beta$-HSD2 mRNA expression or in the UFF/UFE ratio was found between groups with no proteinuria, microalbuminuria, moderate or severe proteinuria. In contrast, the urinary $(\mathrm{THF}+\alpha \mathrm{THF}) / \mathrm{THE}$ ratio increased significantly $(P<0.05)$ in patients with severe albuminuria, suggesting increased hepatic 11ß-HSD1 in those patients.

Conclusions: These data suggest that renal $11 \beta-H S D 2$ expression may be represented only marginally better, if at all, by the UFF/UFE than by the (THF $+\alpha$ THF)/THE ratio. Reduced renal 11 $\beta$-HSD2 expression may lead to occupancy of the MR by glucocorticoids such as cortisol and may contribute to the increased sodium retention seen in patients with impaired renal function.
\end{abstract}

European Journal of Endocrinology 153 291-299

\section{Introduction}

Two distinct isozymes of $11 \beta$-hydroxysteroid dehydrogenase (11ß-HSD) catalyse the interconversion of hormonally active cortisol $(\mathrm{F})$ and inactive cortisone (E) $(1-3)$. In human tissues the type 1 enzyme (11ß-HSD1) is widely distributed but most abundant in liver and adipose tissue. It functions mainly as an oxoreductase converting $\mathrm{E}$ to $\mathrm{F}$. Conversely, in adult tissues the type 2 isozyme (11ß-HSD2) is found predominantly in mineralocorticoid receptor (MR) target tissues, kidney, colon and salivary gland, where it serves to protect the MR from glucocorticoid excess. The MR has the same affinity for cortisol and aldosterone in vitro (4), and the inactivation of $\mathrm{F}$ to $\mathrm{E}$ by $11 \beta$-HSD2 at the site of the MR enables aldosterone to bind to this receptor in vivo $(5,6)$. Mutations in the gene encoding 11ß-HSD2 (HSD11B2) account for an inherited form of hypertension, the syndrome of Apparent Mineralocorticoid Excess (AME) where F induces hypertension and hypokalaemia (7-11). A similar clinical picture to AME occurs following the ingestion of liquorice and carbenoxolone, which are competitive inhibitors of 11ß-HSD2 (12). Increased sensitivity to salt is a forerunner to 'essential' hypertension and polymorphic variability in the HSD11B2 gene with an impaired 11ß-HSD2 activity in part determines salt sensitivity $(11,13,14)$. Evidence suggests impaired $11 \beta$-HSD2 activity in some patients with hypertension but also in patients with renal disease where it may contribute to sodium retention, oedema and hypertension. To date, these studies have relied upon 
urinary F metabolite analyses as markers of renal $11 \beta$ HSD2 activity $(15,16)$. For the first time, we have directly assessed human renal 11ß-HSD2 mRNA expression and correlated this to urinary $\mathrm{F}$ metabolite ratios. We also investigated renal 11ß-HSD2 mRNA expression and urinary $\mathrm{F}$ metabolite ratios in patients with impaired renal function and proteinuria.

\section{Materials and methods}

\section{Subjects}

All patients $(n=95)$ were recruited from the Department of Nephrology, Queen Elizabeth Hospital, Birmingham, UK, and underwent kidney biopsies because of suspected underlying renal disease having presented with unexplained protein- and/or haematuria and/or a rise in serum creatinine concentrations. Patients with acute renal failure were excluded as were those taking spironolactone or prednisolone. Other forms of secondary hypertension, e.g. renal artery stenosis, were excluded. The study had the approval of the local research ethics committee, and all patients had given written informed consent prior to inclusion in the study.

Blood pressure was measured three times before the kidney biopsy and the average was calculated. Height and weight were recorded for body mass index (BMI) calculations. Basic demographic data, information on associated diseases, and current medication were obtained for all subjects. For renal biopsies we used a standard 16-gauge needle with a semi-automatic gun delivering a tissue biopsy cylinder measuring approximately 1.5 to $2 \mathrm{~cm}$ in length and $1 \mathrm{~mm}$ in width. Renal biopsy material was simultaneously analysed for histology and tissue was rapidly frozen at $-80{ }^{\circ} \mathrm{C}$ for further processing. Histological diagnoses were made on the formalin-saline and glutaraldehyde fixed biopsy by established methods using light microscopy, immunohistochemistry, and electron microscopy.

\section{Serum and urine sampling}

Urea, creatinine, albumin, electrolytes (sodium, potassium, chloride, magnesium), haemoglobin, platelets, bilirubin and apertate aminotransferase (AST) were measured in serum samples using standard laboratory methods (Instrumentation Laboratory, Birchwood Warrington, UK). Creatinine clearance (CCR) was calculated by the Cockroft-Gault's formula (17): CCR $(\mathrm{ml} / \mathrm{min})=[1.23$ (for men) or 1.04 (for women) $\times$ $(140($ age $) \times$ weight $(\mathrm{kg})] /$ serum creatinine $(\mu \mathrm{mol} / \mathrm{l})$. Additional calculations were performed using the Modification of Diet in Renal Disease (MDRD) study equation (glomerular filtration rate (GFR) in $\mathrm{ml} / \mathrm{min} / 1.73 \mathrm{~m}^{2}=170$ [plasma-creatinine in $\mathrm{mg} / \mathrm{dl}]^{-0.989} \times[\text { age }]^{-0.176} \times[0.762$ if patient is female $] \times[1.18$ if patient is black $] \times[$ serum urea nitrogen in $\mathrm{mg} / \mathrm{dl}]^{-0.17} \times[$ serum albumin in $\mathrm{g} / \mathrm{dl}]^{+0.318}$ ) (18). This estimate of renal function by the MDRD study equation did not significantly alter our observations using the Cockroft-Gault's formula.

Twenty-four-hour urine sampling was performed at least one day prior to kidney biopsies. Creatinine, albumin and electrolytes were measured in urine samples.

\section{Urinary steroid analysis}

Urinary free cortisol (UFF), free cortisone (UFE), tetrahydrocortisol (THF), $5 \alpha$-tetrahydrocortisol ( $\alpha \mathrm{THF}$ ) and tetrahydrocortisone (THE) were analysed using gas chromatography/mass spectrometry as previously described (19).

\section{RNA extraction and RT}

Kidney biopsies were homogenised on ice using a metal Ultra-Turrax homogeniser treated with RNase Zap (Ambion Ltd., Huntingdon, Cambridgeshire, UK). After homogenisation, samples were centrifuged at $12000 \boldsymbol{g}$ for $10 \mathrm{~min}$ at $4^{\circ} \mathrm{C}$. Total RNA was extracted from supernatants using the Tri Reagent extraction method (Sigma, UK). RNA integrity was assessed by electrophoresis on $1 \%$ agarose gels and the quantity determined spectrophotometrically at $\mathrm{OD}_{260}$. RNA was processed into cDNA as previously described (20).

\section{Quantitative RT-PCR}

Expression of 11ß-HSD2 mRNA was analysed using an ABI Prism 7700 sequence detection system (PerkinElmer Applied Biosystems, Beaconsfield Bucks, UK) that employs TaqMan chemistry for highly accurate quantification of mRNA levels as previously described (21). Reactions were performed in 25- $\mu \mathrm{l}$ volumes on 96 -well plates, in buffer containing TaqMan Universal PCR Master Mix (Applied Biosystems, Foster City, CA, USA) and $25 \mathrm{ng}$ cDNA template. All reactions were multiplexed with the housekeeping gene 18S (Perkin-Elmer). Reactions were as follows: $50{ }^{\circ} \mathrm{C}$ for $2 \mathrm{~min}, 95^{\circ} \mathrm{C}$ for $10 \mathrm{~min}$, and then 44 cycles of $95^{\circ} \mathrm{C}$ for $15 \mathrm{~s}$ and $60^{\circ} \mathrm{C}$ for $1 \mathrm{~min}$. Oligonucleotide primers and a TaqMan probe for $11 \beta$-HSD2 were as follows: forward, 5'-GGGCCTATGGAACCTCCAA-3'; reverse 5'-GACCCACGTTTCTCACTGACTCT-3'; probe 5'-CCGTGGCGCTACTCATGGACACA-3'. The probe was produced by Applied Biosystems (Applied Biosystems UK, Woolston, Warrington). According to the manufacturer's guidelines, data were expressed as CT values (the cycle number at which logarithmic PCR plots cross a calculated threshold line) and used to determine $\Delta \mathrm{CT}$ values $(\Delta \mathrm{CT}=\mathrm{CT}$ of the target gene minus $\mathrm{CT}$ of the housekeeping gene; high $\Delta \mathrm{CT}$ values represent low levels of expression). Fold changes in expression were calculated according to the transformation: fold increase $=2^{- \text {difference in } \Delta \mathrm{CT}}$. The $\mathrm{CT}$ values of $11 \beta$ HSD2 expression measured by real-time PCR varied 
between 21 and 38 cycles with an overall mean of 31 cycles, and the CT values of $18 \mathrm{~S}$ expression varied between 12 and 25 cycles with an overall mean of 19 cycles.

\section{Immunofluorescence and confocal laser microscopy}

Immunofluorescence and confocal laser microscopy for $11 \beta$-HSD2 were performed as previously described (22). Briefly, the processed sections were incubated with a 1:25 dilution of 11 $\beta$-HSD2 antiserum for $60 \mathrm{~min}$, washed in PBS for $10 \mathrm{~min}$, and then incubated with a 1:25 dilution of an antidonkey sheep fluorescent conjugate (Binding Site, Birmingham, UK) for $30 \mathrm{~min}$. Sections were washed in PBS for 60 min and then counterstained with the nuclear-specific propidium iodide and rinsed in PBS. Sections were mounted in glycerol containing 1,4-diazabicyclo(2.2.2) octane and examined under a Zeiss Universal fluorescent microscope as previously reported (23). A Bio-Rad 500 laser scanning confocal system (Bio-Rad, Richmond, CA, USA) attached to a Leitz SM-Lux microscope (Leitz, Rockleigh, NJ, USA) was used to analyse the sections through an optical section of approximately $0.1 \mu \mathrm{m}$, as described previously $(22,24)$. Biopsies from 10 patients were analysed in a blinded fashion by two independent investigators. Five 'normal' biopsies were from patients with microscopic haematuria, normal protein excretion and normal renal function, the other 5 biopsies were from patients with impaired renal function (creatinine clearance $<60 \mathrm{ml} / \mathrm{min}(25)$ ). For each patient, five randomly selected microscopic fields were used to determine the area of $11 \beta-H S D 2$ positive-stained cells compared with the total remaining renal tissue.

\section{Statistical analysis}

Data are expressed as means \pm s.D. unless otherwise stated. Statistical analysis on real-time PCR data were performed on mean $\Delta \mathrm{CT}$ values (and not on fold changes) to exclude potential bias owing to averaging data that had been transformed through the equation $2^{-\Delta \Delta C T}$. Statistical analysis of comparisons between groups was undertaken using paired and unpaired t-tests where appropriate, otherwise the Mann-Whitney Rank Sum Test was used. For correlations, a stepwise multiple regression analysis, including corrections for multiple comparisons, was performed using the SPSS software package (SPSS Inc., Chicago, IL, USA) as well as Pearson's correlations.

\section{Results}

\section{Clinical data}

Fifty-three patients were men, and forty-two were women. Seventy-six patients were of Caucasian origin, twelve of Asian and seven of African-Caribbean origin. The main diagnoses are shown in Table 1. The most frequent diagnosis was thin glomerular basement disease. Those patients received a biopsy mostly due to persistent microscopic haematuria. They showed very thin basement membranes on electron microscopy and usually had a good prognosis if there were no additional risk factors present such as hypertension. The second most frequent diagnosis was chronic ischaemic renal damage, including hypertensive damage, which is common in renal biopsy specimens from middle aged and old people. In our population IgA nephropathy was the third most common diagnosis. These specimens were taken to investigate macroscopic haematuria and showed immunhistochemical deposition of $\operatorname{IgA}$. The rest of our population consisted of a very broad spectrum of different diagnoses reflecting referral to the specialised nephrology services at a UK university hospital. Relevant clinical data (median, range) were as follows: age 49.3 years $(18-83$ years), BMI $26.8 \mathrm{~kg} / \mathrm{m}^{2}\left(16.6-44.5 \mathrm{~kg} / \mathrm{m}^{2}\right)$, systolic blood pressure $134 \mathrm{mmHg} \quad(90-171 \mathrm{mmHg})$, diastolic pressure $74 \mathrm{mmHg}(45-96 \mathrm{mmHg})$, and mean arterial pressure $94 \mathrm{mmHg} \quad(60-117 \mathrm{mmHg})$ Clinically relevant laboratory results (median, range) were as follows: serum albumin $38.3 \mathrm{~g} / \mathrm{l}(10-50 \mathrm{~g} / \mathrm{l})$, urea 10.0 $\mathrm{mmol} / \mathrm{l}(2.2-35.6 \mathrm{mmol} / \mathrm{l})$, haemoglobin $7.8 \mathrm{mmol} / \mathrm{l}$ $(=12.6 \mathrm{~g} / \mathrm{dl})(3.8-11 \mathrm{~mol} / \mathrm{l}=6.1-17.7 \mathrm{~g} / \mathrm{dl})$, platelets $258 \times 10^{6} / \mathrm{ml}\left(121-614 \times 10^{6} / \mathrm{ml}\right)$, serum creatinine $\quad 177 \mu \mathrm{mol} / \mathrm{l} \quad(67-1110 \mu \mathrm{mol} / \mathrm{l})$, creatinine clearance $68.6 \mathrm{ml} / \mathrm{min}(7.4-150.6 \mathrm{ml} / \mathrm{min})$, urinary albumin excretion $1.25 \mathrm{~g} / 24 \mathrm{~h}(0-18.0 \mathrm{~g} / 24 \mathrm{~h})$. Men presented with higher systolic $(139.5 \pm 15.6 \mathrm{mmHg}$ vs $127.6 \pm 18.8 \mathrm{mmHg} ; \quad P<0.005)$ and diastolic $(76.6 \pm 8.8 \mathrm{mmHg}$ vs $71.4 \pm 12.9 \mathrm{mmHg} ; \quad P<0.05)$ blood pressure than women, and with a lower creatinine clearance than women $(59.7 \pm 40.0 \mathrm{ml} / \mathrm{min}$ vs $78.3 \pm 30.1 \mathrm{ml} / \mathrm{min} ; P<0.05)$. Forty-four patients had an underlying diagnosis of hypertension. In total, 48 patients received anti-hypertensive therapy due to

Table 1 Principal histological diagnosis of patients $(n=95)$ who underwent renal biopsy.

Thin glomerular basement membrane disease 23

Chronic ischaemic renal damage 22

IgA nephropathy

Focal segmental sclerosing GN

Diabetic glomerulopathy

Lupus nephritis

Mild IgM mesangial GN

Vasculitis

Nodular light chain glomerulopathy with myeloma

Amyloidosis

Minimal change nephropathy

Membranous nephropathy with renal vasculitis Interstitial nephritis

Metastatic carcinoma in kidney

GN, glomerulonephritis. 
hypertension and/or proteinuria: 14 single therapy, 22 with double therapy, 6 with three medications and 6 with four medications; 18 of them received furosemide, 14 angiotensin converting enzyme (ACE) inhibitors, 5 thiazides given either as single therapy or in combination among each other or in combination with Ca-antagonists or $\beta$-blockers.

\section{Urinary cortisol metabolites and 11 $\beta$-HSD2 mRNA expression}

Using a cut-off of $60 \mathrm{ml} / \mathrm{min}$ for creatinine clearance (25), 58 patients had good or slightly impaired renal function and 37 patients moderately or severely impaired renal function. Patients with decreased renal function had higher systolic $(142.7 \pm 15.6 \mathrm{mmHg}$ vs $128.9 \pm 17.4 \mathrm{mmHg} ; \quad P<0.001)$ and diastolic (77.3 $\pm 11.0 \mathrm{mmHg}$ vs $72.5 \pm 10.7 \mathrm{mmHg} ; P<0.05)$ blood pressure. Patients with decreased renal function showed decreased $11 \beta-H S D 2$ mRNA expression $(\Delta \mathrm{CT}$ : $13.5 \pm 3.0$ vs $11.6 \pm 2.5 ; P<0.005)$. Accordingly, $11 \beta$-HSD2 mRNA expression correlated significantly $(r=0.284 ; P<0.01)$ with renal function (Fig. 1). Patients with decreased renal function had significantly higher UFF/UFE $(1.12 \pm 0.54$ vs $0.89 \pm 0.48 ; P<0.05)$ (Fig. 2A) and (THF $+\alpha \mathrm{THF}) / \mathrm{THE}$ ratios $(1.81 \pm 0.80$ vs 1.24 $\pm 0.66 ; P<0.001$ ) (Fig. $2 \mathrm{~B}$ ). We did not find a significant correlation between total amount of cortisol metabolites and renal function. 11ß-HSD2 mRNA expression correlated significantly with the UFF/UFE ratio $(r=0.276 ; P<0.05)$ (Fig. $3 \mathrm{~A})$ as well as with the urinary (THF $+\alpha \mathrm{THF}) / \mathrm{THE}$ ratio $(r=0.256$; $P<0.05)$ (Fig. 3B).

After correction for age and renal function no gender difference was found in $11 \beta$-HSD2 mRNA expression or in urinary cortisol metabolites. No correlation was found between systolic or diastolic blood pressure, urinary $\mathrm{Na} / \mathrm{K}$ ratio and $11 \beta-\mathrm{HSD} 2$ mRNA expression or urinary cortisol metabolites ratios.

We analysed the data with regard to urinary albumin excretion $(26,27)$ : patients with no albuminuria $(<30 \mathrm{mg} / 24 \mathrm{~h}, \quad n=30)$, with microalbuminuria $(30-300 \mathrm{mg} / 24 \mathrm{~h}, n=26)$, with moderate albuminuria $(300 \mathrm{mg}-2 \mathrm{~g} / 24 \mathrm{~h}, \quad n=17)$ and with severe

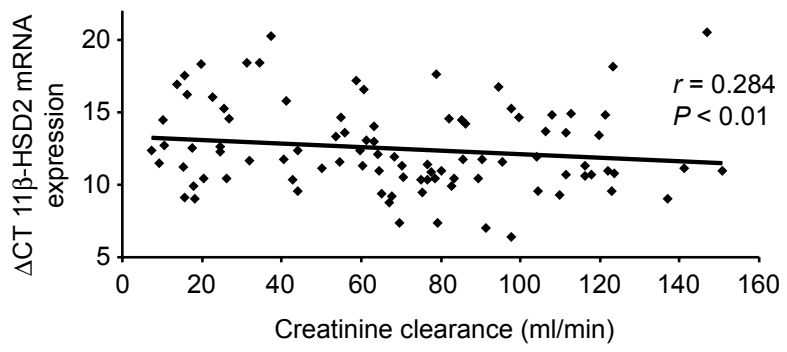

Figure 1 Tissue 11 $\beta$-HSD2 mRNA expression (in $\triangle C T$ values) in renal biopsies from 95 patients in correlation to their renal function (creatinine clearance). High $\Delta C T$ values represent low levels of expression and vice versa.
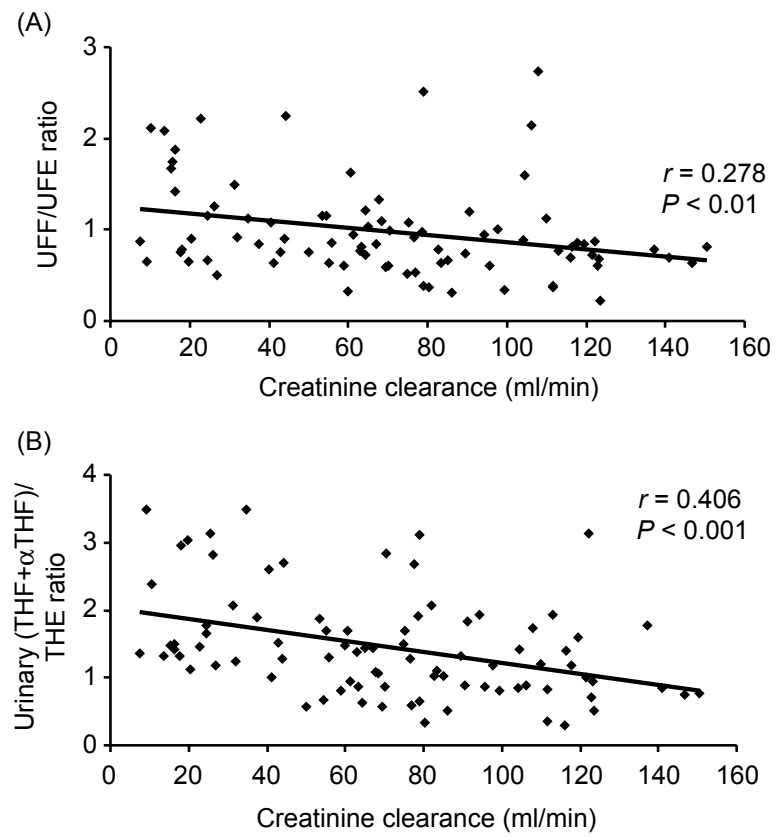

Figure 2 Correlation between renal function (creatinine clearance) and $(A)$ the urinary free cortisol/urinary free cortisone (UFF/UFE) ratio, and (B) the urinary (tetrahydrocortisol (THF) $+\alpha \mathrm{THF}) /$ tetrahydrocortisone (THE) ratio in 95 patients receiving renal biopsy.
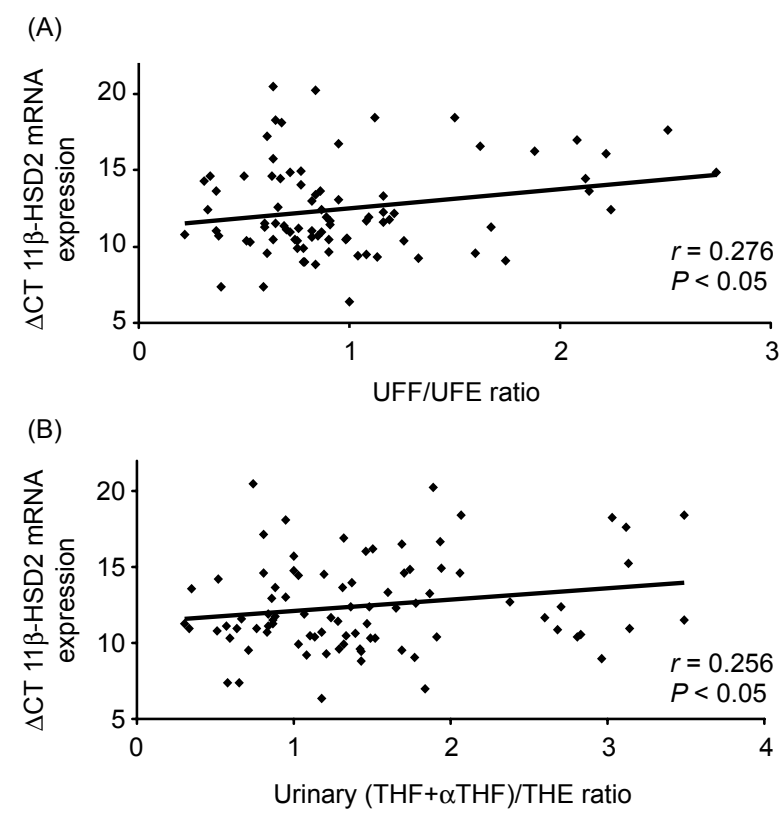

Figure 3 Correlation between tissue $11 \beta$-HSD2 mRNA expression (in $\triangle \mathrm{CT}$ values) and (A) the urinary free cortisol/ urinary free cortisone (UFF/UFE) ratio, and (B) the urinary (tetrahydrocortisol (THF) $+\alpha \mathrm{THF}$ )/tetrahydrocortisone (THE) ratio in 95 patients receiving renal biopsy. High $\triangle C T$ values represent low levels of expression and vice versa. 
albuminuria $(>2 \mathrm{~g} / 24 \mathrm{~h}, \quad n=14)$. As predicted, patients with no albuminuria had the best renal function (creatinine clearance: $88.3 \pm 29.1 \mathrm{ml} / \mathrm{min}$ vs microalbuminuria: $59.5 \pm 40.1 \mathrm{ml} / \mathrm{min} \quad(P<0.005)$, moderate albuminuria: $64.8 \pm 36.5 \mathrm{ml} / \mathrm{min}(P<0.05)$, and severe albuminuria: $\quad 50.0 \pm 31.7 \mathrm{ml} / \mathrm{min}$ $(P<0.001)$, the lowest systolic $(127.6 \pm 18.4 \mathrm{mmHg}$ vs $135.3 \pm 15.2 \mathrm{mmHg}$ (not significant (n.s.)), $143.1 \pm 14.1 \mathrm{mmHg}(P<0.005), 144.0 \pm 17.1 \mathrm{mmHg}$ $(P<0.05)$ respectively) and lowest diastolic (71.0 $\pm 10.4 \mathrm{mmHg}$ vs $74.2 \pm 11.0 \mathrm{mmHg}$ (n.s.), $79.1 \pm 8.6 \mathrm{mmHg}(P<0.01), 78.1 \pm 10.1 \mathrm{mmHg}$ (n.s.) respectively) blood pressure. We found no significant difference in 11ß-HSD2 mRNA expression (Fig. 4) or UFF/UFE ratio (Fig. 5) between the groups with different severity of albuminuria, but patients with severe proteinuria had significantly increased urinary $(\mathrm{THF}+\alpha \mathrm{THF}) / \mathrm{THE}$ ratio $(2.05 \pm 0.83$ vs no albuminuria: $1.37 \pm 0.83 \quad(P<0.05)$, microalbuminuria: $1.58 \pm 1.15$ (n.s.), moderate albuminuria: $1.36 \pm 0.65$ $(P<0.05)$ ) (Fig. 5). No change in the urinary THF/ $\alpha$ THF ratio reflecting $5 \alpha$-reductase activity was found between the groups (Fig. 5). No significant difference in 11 $\beta$-HSD2 mRNA expression, and urinary UFF/UFE and THF/ $\alpha$ THF ratios was found between the groups of diagnosis. We could not detect a difference in $11 \beta$-HSD2 expression between patients who received ACE inhibitors and/or thiazides and/or furosemide, compared with those on no medication after adjustment for age and renal function.

\section{Immunofluoresence}

Compared with the intense expression of $11 \beta-H S D 2$ immunoreactive protein in collecting ducts in kidneys from two patients with 'normal' renal function (Fig. 6A and B), a much weaker $11 \beta$-HSD2 immunofluoresence signal was found in renal biopsies from

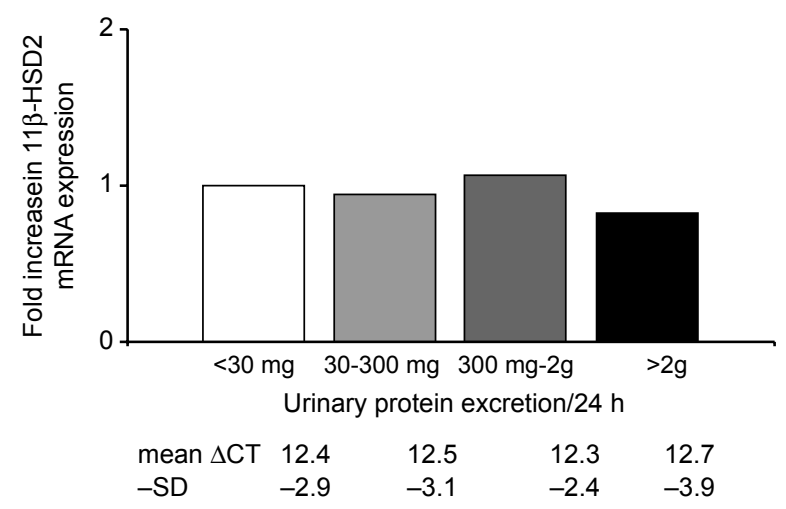

Figure 4 Fold increase in $11 \beta-H S D 2$ mRNA expression in renal biopsies from 95 patients in relation to the severity of their proteinuria. $11 \beta-H S D 2$ mRNA expression in patients with no proteinuria $(<30 \mathrm{mg} / 24 \mathrm{~h})$ was set at 1 .

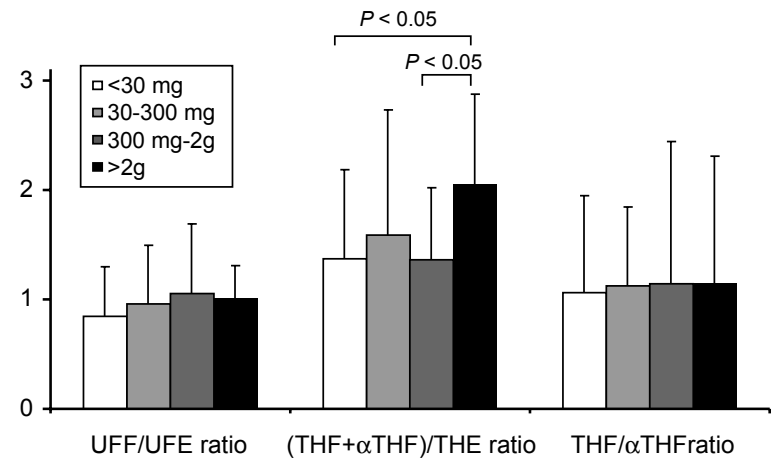

Figure 5 Urinary free cortisol/urinary free cortisone (UFF/UFE) ratio, urinary (tetrahydrocortisol(THF) $+\alpha \mathrm{THF}$ )/tetrahydrocortisone (THE) ratio and urinary THF/ $\alpha$ THF ratio in 95 patients in relation to the severity of their proteinuria.

four patients with an impaired renal function (creatinine clearance $<60 \mathrm{ml} / \mathrm{min}$ (25)) (Fig. 6C to F). Semi-quantitative analysis of $11 \beta$-HSD 2 immunofluoresent-positive cells revealed significantly more positive staining in correlation to the remaining renal tissue in biopsies from patients with 'normal' renal function $(n=5)$ than from patients with impaired renal function $(n=5)$ (Fig. 7$)$.

\section{Discussion}

In the human kidney, $11 \beta$-HSD2 is expressed in cortical and medullary collecting ducts $(22)$ as well as in the glomerulus (28), and is responsible for the conversion of cortisol to hormonally inactive cortisone thus conferring the in vivo specificity of the MR for aldosterone $(5,6)$.

At the present time, cortisol and its urinary metabolites (cortisone, THF, $\alpha$ THF and THE) are measured as surrogate markers for the in vivo assessment of $11 \beta$-HSD1 and -2 activities. The urinary (THF + $\alpha \mathrm{THF} / \mathrm{THE}$ ratio has historically been used to diagnose 11ß-HSD2-deficient states, such as $\operatorname{AME~}(3,29,30)$, but has also been used to estimate hepatic 11 1 -HSD 1 activity $(31-34)$. The ratio probably provides an index of 'global' $11 \beta$-HSD activity within the body, i.e. principally $11 \beta$-HSD 1 in the liver and fat and

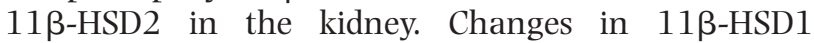
activity may be reflected by the urinary (THF + $\alpha \mathrm{THF}) / \mathrm{THE}$ ratio, but only if $11 \beta-\mathrm{HSD} 2$ and $5 \alpha-$ and $5 \beta$-reductase activities are not altered (the latter assessed by the THF/ $\alpha \mathrm{THF}$ ratio). In contrast, we and others have suggested that renal 11ß-HSD2 activity may be better reflected by the urinary free cortisol/free cortisone (UFF/UFE) ratio than by the (THF + $\alpha$ THF)/THE ratio $(19,35,36)$. Normal subjects excrete two- to threefold more urinary free cortisone than free cortisol, indicative of renal $11 \beta-H S D 2-m e d i a t e d$ conversion of cortisol to cortisone (37). In AME, UFE 

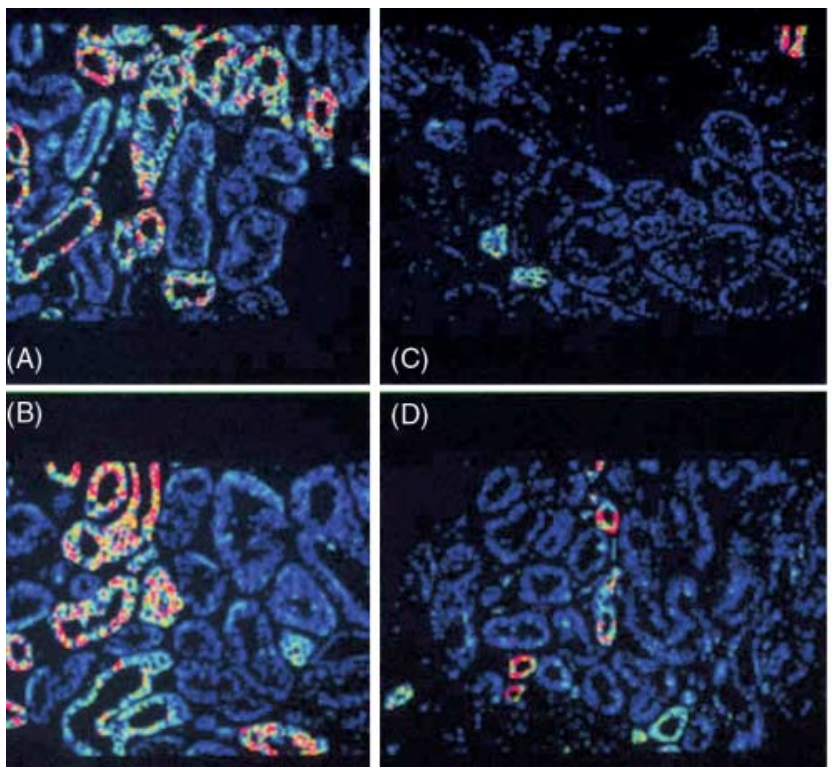

excretion is virtually undetectable (19) resulting in a high UFF/UFE ratio. Serum cortisol and cortisone concentrations have been used in a number of studies $(20,38-41)$. Whitworth et al. documented reduced plasma cortisone concentrations in patients with loss of renal function (37), which was confirmed by other investigators $(39-41)$.

For the first time, we were able to measure $11 \beta$-HSD2 mRNA expression in renal biopsies of 95 patients. We have to emphasise that the results of our $11 \beta$-HSD2 mRNA expression data have to be interpreted carefully due to the fact that the kidney is a very heterogenous organ and, in renal biopsies, the ratios between various anatomical structures might vary considerably. In addition, our data are difficult to interpret due to the additional facts of interindividual differences in salt intake, the broad spectrum of

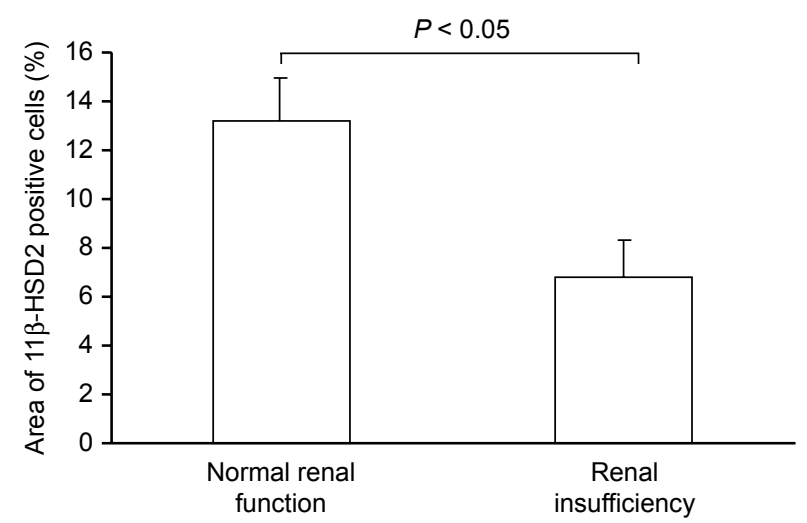

Figure 7 Area of $11 \beta-H S D 2$ immunofluoresent positive cells in relation to the remaining renal tissue in kidney biopsies from 5 patients with normal renal function and 5 patients with renal insufficiency. Results are means \pm S.E.M.
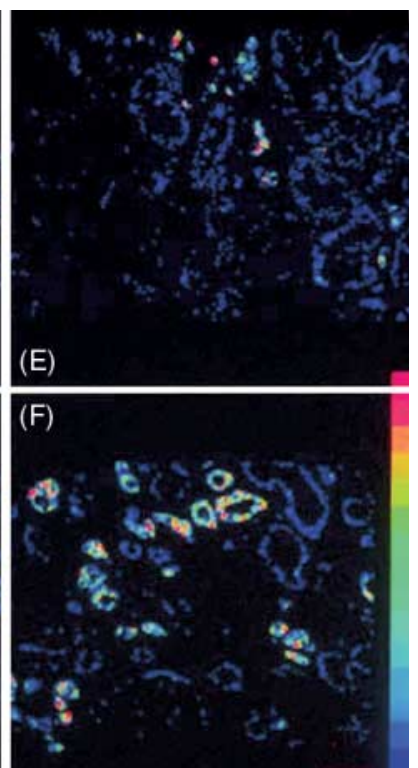

Figure 6 Confocal laser microscopy of $11 \beta$-HSD2 immunofluoresence in kidney biopsies. The images depict the distribution of immunofluoresence signal as scanned through an optical section of approximately $0.1 \mu \mathrm{m}$. The merged images of epithelial cells in collecting ducts stained with $11 \beta$-HSD2 antiserum (green signal) and propidium iodide (red signal) to highlight nuclei are shown from two normal biopsies $(\mathrm{A}, \mathrm{B})$ and four biopsies from patients with renal disease and loss of renal function (C-F).

different histological diagnoses and the number of antihypertensive drugs prescribed.

We correlated the $11 \beta-H S D 2$ mRNA expression data to urinary cortisol metabolite ratios. We observed that the UFF/UFE ratio was significantly negatively correlated with renal $11 \beta-H S D 2$ mRNA expression; a low UFF/UFE ratio corresponded to a high 11ß-HSD2 mRNA expression. The urinary (THF $+\alpha \mathrm{THF}) / \mathrm{THE}$ ratio was also negatively correlated with renal $11 \beta$ HSD2 mRNA expression. However, in specific situations the urinary $(\mathrm{THF}+\alpha \mathrm{THF}) / \mathrm{THE}$ ratio may be misleading if used as the sole evaluation of $11 \beta$-HSD2 activity. Thus, when we divided our patients into groups with no proteinuria, microalbuminuria, moderate and severe proteinuria, although there was no change in $11 \beta$-HSD2 mRNA expression or the UFF/UFE ratio between the groups, the urinary (THF $+\alpha \mathrm{THF}) / \mathrm{THE}$ ratio was increased in patients with severe proteinuria. We suggest that this increased urinary (THF + $\alpha \mathrm{THF}) / \mathrm{THE}$ ratio is likely to reflect increased hepatic $11 \beta$-HSD1. In patients with nephrotic syndrome, an increase in the urinary (THF $+\alpha \mathrm{THF}) / \mathrm{THE}$ ratio was observed by Vogt et al. (15), but interpreted as an impaired 11 $\beta$-HSD2 activity, yet neither UFF nor UFE were measured. In an additional study by Vogt et al. (42) using rats with puromycin aminonucleoside (PAN)-induced proteinuria and with adriamycin nephrosis, the authors showed an increased urinary $\mathrm{TH}$-corticosterone $+\alpha \mathrm{TH}$-corticosterone)/11-dehydro$\mathrm{TH}$-corticosterone ratio which is in accordance with our finding in patients with nephrotic syndrome. In contrast to Vogt et al., we believe our evidence suggests that this altered ratio is due to increased hepatic $11 \beta$ HSD1 activity rather than decreased 11 -HSD2 activity, because 11ß-HSD2 mRNA expression and the UFF/UFE ratio were not altered in this group. 
The cause of this putative upregulation of hepatic $11 \beta$-HSD1 activity proposed by us remains to be elucidated.

Due to our findings, we suggest that human renal $11 \beta-H S D 2$ mRNA expression decreases with impairment of renal function and this is correlated with the UFF/UFE and the (THF $+\alpha \mathrm{THF}) / \mathrm{THE}$ ratio. In addition, we performed immunofluorescence and confocal laser microscopy for 11ß-HSD2 in a smaller number of renal biopsies and found that protein expression was also diminished in patients with loss of renal function. But it must be taken into account that our protein expression data is semi-quantitative at best and needs to be interpreted with care. Nevertheless, our data are supported by earlier clinical studies: patients with chronic renal failure have a prolonged plasma cortisol half-life $(2.9 \mathrm{~h}$ compared with $2.1 \mathrm{~h}$ in controls) (43), and plasma cortisone concentrations have been shown to be inversely correlated with plasma creatinine concentrations $(37,39,40,44)$.

In our study, the reason for the diminished $11 \beta-H S D 2$ expression in renal disease is unknown. Zaehner et al. (45) screened 587 subjects, including 260 patients with end-stage renal disease, for mutations in exons 2 through 5 of the HSD11B2 gene, and found a high prevalence of single-nucleotide polymorphisms (SNPs) but no exonic mutations. It is unknown if these might result in altered 11 $\beta$-HSD2 mRNA expression. A further factor may be hypoxia, which is known to be associated with several renal tubular diseases. Hypoxia has been shown to significantly decrease $11 \beta$-HSD2 in ovine fetal kidney (46). Heiniger et al. (47) have documented decreased renal 11 $\beta$-HSD2 mRNA levels after induction of unilateral renal ischaemia in rats, thought to be mediated by MAP kinase-dependent upregulation of the early growth response gene (Egr-1). Besides tubular expression, $11 \beta-H S D 2$ is reported to be found in the glomerulus (28), but its specific glomerular function is not known. It might regulate the access of cortisol to glomerular glucocorticoid and/or mineralocorticoid receptors, and its dysregulation might be involved in glomerular disease.

Despite the limitations of our study and the difficulties of interpretation, as pointed out above, we suggest that the defective renal cortisol metabolism with consequent access of cortisol to the MR could contribute to some of the consequences of renal disease, such as hypertension and sodium retention, or may modify others, such as hyperkalaemia and decreased glomerular filtration rate. Several authors have also suggested that impaired 11ß-HSD2 activity may be involved in the pathogenesis of essential hypertension (48-50). However, in our study involving patients with a diversity of renal diseases, no relationship was found between the UFF/UFE ratio or $11 \beta$-HSD2 mRNA expression and electrolytes or blood pressure.
Taking the limitations of our study into account, we think to have shown reduced expression of renal $11 \beta$-HSD2 in patients with impaired renal function. Our data indicate that this is not influenced by underlying proteinuria or a diagnosis of hypertension but may be directly correlated with kidney function as reflected by creatinine clearance. In addition to secondary hyperaldosteronism as a consequence of renal hypoperfusion, impaired 11 $\beta$-HSD2 expression may lead to occupancy of the MR by glucocorticoids such as cortisol and may contribute to the increased sodium retention seen in patients with impaired renal function. In addition, this study suggests that the UFF/UFE ratio directly correlates with renal $11 \beta$-HSD2 expression and activity and that the $\mathrm{UFF} / \mathrm{UFE}$ ratio is only marginally better, if at all, than the urinary $(\mathrm{THF}+\alpha \mathrm{THF}) / \mathrm{THE}$ ratio.

\section{Acknowledgements}

We would like to thank A Howie, Department of Pathology, Queen Elizabeth Hospital, University of Birmingham, Birmingham, UK, for the diagnoses of the renal biopsies. This work was supported by the Deutsche Forschungsgemeinschaft (DFG postdoctoral research fellowship grant (QU142/1-1) to M Q), by the Medical Research Council (MRC core co-op grants to P M S and $\mathrm{M} \mathrm{H}$ ), and by the Wellcome Trust (programme grant to $\mathrm{P} \mathrm{M} \mathrm{S}$ ).

\section{References}

1 Albiston AL, Obeyesekere VR, Smith RE \& Krozowski ZS. Cloning and tissue distribution of the human $11 \beta$-hydroxysteroid dehydrogenase type 2 enzyme. Molecular and Cellular Endocrinology 1994105 R11-R17.

2 Tannin GM, Agarwal AK, Monder C, New MI \& White PC. The human gene for $11 \beta$-hydroxysteroid dehydrogenase: structure, tissue distribution, and chromosomal localization. Journal of Biological Chemistry 1991266 16653-16658.

3 Stewart PM \& Krozowski ZS. 11ß-Hydroxysteroid dehydrogenase. Vitamins and Hormones 199957 249-324.

4 Arriza JL, Weinberger C, Cerelli G, Glaser TM, Handelin BL, Housman DE \& Evans RM. Cloning of human mineralocorticoid receptor complementary DNA: structural and functional kinship with the glucocorticoid receptor. Science 1987237 268-275.

5 Edwards CR, Stewart PM, Burt D, Brett L, McIntyre MA, Sutanto WS, de Kloet ER \& Monder C. Localisation of $11 \beta$ hydroxysteroid dehydrogenase - tissue specific protector of the mineralocorticoid receptor. Lancet $19882986-989$.

6 Funder JW, Pearce PT, Smith R \& Smith AI. Mineralocorticoid action: target tissue specificity is enzyme, not receptor, mediated. Science $1988242583-585$.

7 Quinkler M, Bappal B, Draper N, Atterbury AJ, Lavery GG, Walker EA, DeSilva V, Taylor NF, Hala S, Rajendra N \& Stewart PM. Molecular basis for the Apparent Mineralocorticoid Excess syndrome in the Oman population. Molecular and Cellular Endocrinology 2004217 143-149.

8 Werder E, Zachmann M, Vollmin JA, Veyrat R \& Prader A. Unusual steroid excretion in a child with low renin hypertension. Research in Steroids 19746 385-389. 
9 New MI, Levine LS, Biglieri EG, Pareira J \& Ulick S. Evidence for an unidentified steroid in a child with apparent mineralocorticoid hypertension. Journal of Clinical Endocrinology and Metabolism $197744924-933$.

10 Ulick S, Levine LS, Gunczler P, Zanconato G, Ramirez LC, Rauh W, Rosler A, Bradlow HL \& New MI. A syndrome of apparent mineralocorticoid excess associated with defects in the peripheral metabolism of cortisol. Journal of Clinical Endocrinology and Metabolism $197949757-764$.

11 Quinkler M \& Stewart PM. Hypertension and the cortisol-cortisone shuttle. Journal of Clinical Endocrinology and Metabolism $2003882384-2392$.

12 Stewart PM, Wallace AM, Valentino R, Burt D, Shackleton CH \& Edwards CR. Mineralocorticoid activity of liquorice: $11 \beta$-hydroxysteroid dehydrogenase deficiency comes of age. Lancet 19872 $821-824$.

13 Agarwal AK, Giacchetti G, Lavery G, Nikkila H, Palermo M, Ricketts M, McTernan C, Bianchi G, Manunta P, Strazzullo P, Mantero F, White PC \& Stewart PM. CA-repeat polymorphism in intron 1 of HSD11B2: effects on gene expression and salt sensitivity. Hypertension 200036 187-194.

14 Lavery GG, McTernan CL, Bain SC, Chowdhury TA, Hewison M \& Stewart PM. Association studies between the HSD11B2 gene (encoding human 11 $\beta$-hydroxysteroid dehydrogenase type 2), type 1 diabetes mellitus and diabetic nephropathy. European Journal of Endocrinology 2002146 553-558.

15 Vogt B, Dick B, N'Gankam V, Frey FJ \& Frey BM. Reduced $11 \beta$-hydroxysteroid dehydrogenase activity in patients with the nephrotic syndrome. Journal of Clinical Endocrinology and Metabolism $199984811-814$.

16 Vierhapper H, Derfler K, Nowotny P, Hollenstein U \& Waldhausl W. Impaired conversion of cortisol to cortisone in chronic renal insufficiency - a cause of hypertension or an epiphenomenon? Acta Endocrinologica $1991 \mathbf{1 2 5} 160-164$.

17 Cockcroft DW \& Gault MH. Prediction of creatinine clearance from serum creatinine. Nephron $19761631-41$.

18 Levey AS, Bosch JP, Lewis JB, Greene T, Rogers N \& Roth D. A more accurate method to estimate glomerular filtration rate from serum creatinine: a new prediction equation. Modification of diet in renal disease study group. Annals of Internal Medicine $1999130461-470$

19 Palermo M, Shackleton CHL, Mantero F \& Stewart PM. Urinary free cortisone and the assessment of $11 \beta$-hydroxysteroid dehydrogenase activity in man. Clinical Endocrinology $1996 \mathbf{4 5} 605-611$.

20 Tomlinson JW, Moore JS, Clark PM, Holder G, Shakespeare L \& Stewart PM. Weight loss increases 11ß-hydroxysteroid dehydrogenase type 1 expression in human adipose tissue. Journal of Clinical Endocrinology and Metabolism $2004892711-2716$.

21 McTernan CL, Draper N, Nicholson H, Chalder SM, Driver P, Hewison M, Kilby MD \& Stewart PM. Reduced placental $11 \beta$-hydroxysteroid dehydrogenase type 2 mRNA levels in human pregnancies complicated by intrauterine growth restriction: An analysis of possible mechanisms. Journal of Clinical Endocrinology and Metabolism 200186 4979-4983.

22 Shimojo M, Ricketts ML, Petrelli MD, Moradi P, Johnson GD, Bradwell AR, Hewison M, Howie AJ \& Stewart PM. Immunodetection of $11 \beta$-hydroxysteroid dehydrogenase type 2 in human mineralocorticoid target tissues: evidence for nuclear localization. Endocrinology $1997 \mathbf{1 3 8} 1305-1311$.

23 Howie AJ \& Johnson GD. Confocal microscopic and other observations on the distal end of the thick limb of the human Loop of Henle. Cell Tissue Research 1992267 11-16.

24 White JG, Amos WB \& Fordham M. An evaluation of confocal versus conventional imaging of biological structures by fluorescence light microscopy. Journal of Cell Biology 1987105 41-48.

25 Couchoud C, Pozet N, Labeeuw M \& Pouteil-Noble C. Screening early renal failure: cut-off values for serum creatinine as an indicator of renal impairment. Kidney International $1999 \mathbf{5 5}$ $1878-1884$
26 Peterson JC, Adler S, Burkart JM, Greene T, Hebert LA, Hunsicker LG, King AJ, Klahr S, Massry SG \& Seifter JL. Blood pressure control, proteinuria, and the progression of renal disease. The modification of diet in renal disease study. Annals of Internal Medicine 1995123 754-762.

27 Remuzzi G \& Tognoni G. Randomised placebo-controlled trial of effect of ramipril on decline in glomerular filtration rate and risk of terminal renal failure in proteinuric, non-diabetic nephropathy. The GISEN Group (Gruppo Italiano Di Studi Epidemiologici in Nefrologia). Lancet 1997349 1857-1863.

28 Kataoka S, Kudo A, Hirano H, Kawakami H, Kawano T, Higashihara E, Tanaka H, Delarue F, Sraer JD, Mune T, Krozowski ZS \& Yan K. 11ß-Hydroxysteroid dehydrogenase type 2 is expressed in the human kidney glomerulus. Journal of Clinical Endocrinology and Metabolism 200287 877-882.

29 Shackleton $\mathrm{CH}$, Rodriguez J, Arteaga E, Lopez JM \& Winter JS. Congenital 11 $\beta$-hydroxysteroid dehydrogenase deficiency associated with juvenile hypertension: Corticosteroid metabolite profiles of four patients and their families. Clinical Endocrinology 198522 $701-712$.

30 Monder C, Shackleton CH, Bradlow HL, New MI, Stoner E, Iohan F \& Lakshmi V. The syndrome of Apparent Mineralocorticoid Excess: its association with $11 \beta$-dehydrogenase and $5 \beta$-reductase deficiency and some consequences for corticosteroid metabolism. Journal of Clinical Endocrinology and Metabolism $1986 \mathbf{6 3}$ $550-557$.

31 Tomlinson JW, Draper N, Mackie J, Johnson AP, Holder G, Wood P \& Stewart PM. Absence of cushingoid phenotype in a patient with Cushing's disease due to defective cortisone to cortisol conversion. Journal of Clinical Endocrinology and Metabolism 2002 87 57-62.

32 Jamieson A, Wallace AM, Andrew R, Nunez BS, Walker BR, Fraser R, White PC \& Connell JM. Apparent Cortisone Reductase Deficiency: a functional defect in $11 \beta$-hydroxysteroid dehydrogenase type 1. Journal of Clinical Endocrinology and Metabolism 1999 $843570-3574$.

33 Phillipov G, Palermo M \& Shackleton CHL. Apparent Cortisone Reductase Deficiency: a unique form of hypercortisolism. Journal of Clinical Endocrinology and Metabolism $1996 \mathbf{8 1} 3855-3860$.

34 Draper N, Walker EA, Bujalska IJ, Tomlinson JW, Chalder SM, Arlt W, Lavery GG, Bedendo O, Ray DW, Laing I, Malunowicz E, White PC, Hewison M, Mason PJ, Connell JM, Shackleton CH \& Stewart PM. Mutations in the genes encoding 11ß-hydroxysteroid dehydrogenase type 1 and hexose-6-phosphate dehydrogenase interact to cause cortisone reductase deficiency. Nature Genetics 200334 434-439.

35 Quinkler M, Oelkers W \& Diederich S. In vivo measurement of renal $11 \beta$-hydroxysteroid dehydrogenase type 2 activity. Journal of Clinical Endocrinology and Metabolism 2000854921 -4922.

36 Best R \& Walker BR. Additional value of measurement of urinary cortisone and unconjugated cortisol metabolites in assessing the activity of 11ß-hydroxysteroid dehydrogenase in vivo. Clinical Endocrinology $199747231-236$.

37 Whitworth JA, Stewart PM, Burt D, Atherden SM \& Edwards CR. The kidney is the major site of cortisone production in man. Clinical Endocrinology 198931 355-361.

38 Tomlinson JW, Crabtree N, Clark PM, Holder G, Toogood AA, Shackleton CH \& Stewart PM. Low-dose growth hormone inhibits $11 \beta$-hydroxysteroid dehydrogenase type 1 but has no effect upon fat mass in patients with simple obesity. Journal of Clinical Endocrinology and Metabolism $2003 \mathbf{8 8} 2113-2118$.

39 Homma M, Tanaka A, Hino K, Takamura H, Hirano T, Oka K, Kanazawa M, Miwa T, Notoya Y, Niitsuma T \& Hayashi T. Assessing systemic 11ß-hydroxysteroid dehydrogenase with serum cortisone/cortisol ratios in healthy subjects and patients with diabetes mellitus and chronic renal failure. Metabolism $200150801-804$.

40 Morineau G, Boudi A, Barka A, Gourmelen M, Degeilh F, Hardy N, Al-Halnak A, Soliman H, Gosling JP, Julien R, Brerault J-L, Boudou P, Aubert P, Villette J-M, Pruna A, Galons H \& Fiet J. Radioimmunoassay of cortisone in serum, urine, and saliva to 
assess the status of the cortisol-cortisone shuttle. Clinical Chemistry 199743 1397-1407.

41 N'Gankam V, Uehlinger D, Dick B, Frey BM \& Frey FJ. Increased cortisol metabolites and reduced activity of $11 \beta$-hydroxysteroid dehydrogenase in patients on hemodialysis. Kidney International $2002611859-1866$.

42 Vogt B, Dick B, Marti HP, Frey FJ \& Frey BM. Reduced 11 betahydroxysteroid dehydrogenase activity in experimental nephrotic syndrome. Nephrology Dialysis Transplantation $2002 \quad 17$ $753-758$.

43 Kawai S, Ichikawa Y \& Homma M. Differences in metabolic properties among cortisol, prednisolone, and dexamethasone in liver and renal diseases: accelerated metabolism of dexamethasone in renal failure. Journal of Clinical Endocrinology and Metabolism $198560848-854$.

44 Srivastava LS, Werk EE Jr, Thrasher K, Sholiton LJ, Kozera R, Nolten W \& Knowles HC Jr. Plasma cortisone concentration as measured by radioimmunoassay. Journal of Clinical Endocrinology and Metabolism 197336 937-943.

45 Zaehner T, Plueshke V, Frey BM, Frey FJ \& Ferrari P. Structural analysis of the $11 \beta$-hydroxysteroid dehydrogenase type 2 gene in end-stage renal disease. Kidney International $2000 \mathbf{5 8}$ $1413-1419$.
46 Murotsuki J, Gagnon R, Pu X \& Yang K. Chronic hypoxemia selectively down-regulates $11 \beta$-hydroxysteroid dehydrogenase type 2 gene expression in the fetal sheep kidney. Biology of Reproduction $199858234-239$.

47 Heiniger CD, Kostadinova RM, Rochat MK, Serra A, Ferrari P, Dick B, Frey BM \& Frey FJ. Hypoxia causes down-regulation of $11 \beta$-hydroxysteroid dehydrogenase type 2 by induction of Egr1. FASEB Journal $200317917-919$.

48 Walker BR, Stewart PM, Shackleton CH, Padfield PL \& Edwards CR. Deficient inactivation of cortisol by $11 \beta$-hydroxysteroid dehydrogenase in essential hypertension. Clinical Endocrinology $199339221-227$.

49 Soro A, Ingram MC, Tonolo G, Glorioso N \& Fraser R. Evidence of coexisting changes in $11 \beta$-hydroxysteroid dehydrogenase and $5 \beta$ reductase activity in subjects with untreated essential hypertension. Hypertension $1995 \mathbf{2 5} 67-70$.

50 Ferrari P \& Krozowski Z. Role of the $11 \beta$-hydroxysteroid dehydrogenase type 2 in blood pressure regulation. Kidney International 200057 1374-1381.

Received 21 December 2004

Accepted 19 April 2005 